\title{
AUDIT SDM (STUDI KASUS di PT “A” JAKARTA)
}

\author{
Gede Umbaran Dipodjoyo \\ Fakultas Psikologi Universitas Persada Indonesia YAI Jakarta \\ umbaran13@gmail.com \\ Ruri Puji Santoso \\ Fakultas Psikologi Universitas Persada Indonesia YAI Jakarta \\ ruripuji@gmail.com
}

\begin{abstract}
Abstrak
Kompetensi karyawan akan sangat menentukan kemajuan perusahaan, walaupun ini juga harus didukung oleh suatu sistem yang sesuai dengan perundangan yang berlaku. Audit Sumber Daya Manusia adalah suatu cara untuk memeriksa pelaksanaan penerapan peraturan yang berlaku. Audit dengan menggunakan Daftar Pertanyaan SA 8000 ini meliputi Pekerja Anak-anak, kerja paksa, keselamatan dan kesehatan, kebebasan berserikat dan hak mengadakan kesepakatan, diskriminasi, praktek pendisiplinan, jam kerja, remunerasi, sistem manajemen SDM serta hal-hal lain. Selanjutnya dilaksanakan juga analisa postensial beberapa karyawan yang ada dengan alat tes psikologi MBTI untuk melihat 4 skala kecenderungan karyawan. Hasil yang dicapai terlihat bahwa aspek sistem manajemen belum terlihat rapi, karena tidak ada nya peraturan baku, semua lebih kepada kebijaksanaan, sehingga banyak timbul rumor, yang berdampak pada hubungan antar katyawan kurang sehat, Sedangkan dalam MBTI mayoritas hasilnya adalah adanya sifat keteraturan dalam bekerja dan menyukai kebersamaan.
\end{abstract}

Kata kunci: audit sumber daya manusia, SA 8000, Hasil MBTI.

Sumber daya manusia (SDM) merupakan faktor utama dalam suatu organisasi. SDM merupakan aset potensial yang dimiliki organisasi dan berperan penting dalam pencapaian tujuan organisasi. Sumber daya manusia diibaratkan sebagai motor penggerak dalam suatu organisasi. Sebagus apapun tujuan, visi, misi, dan strategi sebuah organisasi, tidak akan berguna apabila sumber daya manusianya tidak diperhatikan dan dikelola dengan baik, apapun bentuk dan tujuannya. Organisasi dibuat berdasarkan visi untuk kepentingan manusia, dan pada implementasinya dikelola oleh manusia, oleh karena itu, SDM perlu dikelola dengan baik dan profesional agar dapat tercipta keseimbangan antara kebutuhan SDM dengan tuntutan serta kemajuan bisnis perusahaan.

Audit sumber daya manusia adalah salah satu cara untuk memeriksa fungsifungsi operasional dari perencanaan, penerimaan, seleksi, pelatihan dan pengembangan, penilaian kinerja, kompensasi, hubungan karyawan dengan 
organisasi (hubungan industrial) sudah berjalan sebagaimana mestinya. Audit SDM berfokus pada pencarian data dan informasi tentang permasalahan organisasi dari perspektif SDM, lebih spesifik menyangkut masalah-masalah yang mengakibatkan kegagalan organisasi. Audit sumber daya manusia sebagai suatu analisis dari semua faktor yang menyangkut administrasi personalia diikuti dengan rekomendasi untuk memperbaiki setiap penyimpangan dari standar yang diinginkan (Ranupandojo, 2000). Susilo (2002) menyatakan bahwa audit sumber daya manusia adalah pemeriksaan dan penilaian secara sistematis, objektif dan terdokumentasi terhadap fungsi-fungsi organisasi yang berpengaruh oleh manajemen sumber daya manusia dengan memastikan dipenuhinya azas kesesuaian, efektivitas, dan efisiensi dalam penggunaan sumber daya manusia untuk mendukung tercapainya sasaran fungsional maupun tujuan jangka pendek, jangka menengah dan jangka panjang.

Dengan dilakukannya audit SDM dapat memberikan sumbangan penting dalam pemeliharaan hubungan antara bagian SDM dengan bagian lain diperusahaan. Menurut Sondang Siagian (2013: 354) pentingnya melakukan audit sumber daya manusia dapat dilihat dari beberapa sudut pandang. Pertama, untuk kepentingan pemenuhan berbagai ketentuan perundang-undangan yang berlaku, sehingga dapat menghasilkan informasi kegiatan organisasi yang berkaitan dengan ketentuan dalam perundang-undangan tersebut. Kedua, penerapan sistem imbalan yang memperhatikan berbagai prinsip keadilan, prinsip perbandingan, dan prinsip kewajaran. Ketiga, untuk menjamin aktivitas karyawan sudah berjalan efektif, efisien, dan produktif.

Selain itu, untuk mengetahui potensi karyawan dilakukan pemeriksaan psikologis dengan menggunakan alat test tunggal yaitu Myer Briggs Type Indicator (MBTI) yang mengungkap kepribadian dengan 16 kombinasi (Tim HR Exellency, t.th)

PT. "A" adalah salah satu perusahaan yang bergerak dibidang jasa konsultan teknik arsitektur dan engineering khususnya jasa konstruksi dibidang perencanaan, manajemen konstruksi dan pengawasan. Perusahaan ini berkembang sesuai dengan misi yang dimiliki perusahaan yaitu ikut mendukung pembangunan di Indonesia dan dunia melalui jasa layanan konsultasi teknis dengan kompetensi dan jaminan mutu yang tinggi serta mampu mengadakan dan mengembangkan sumber daya manusia yang handal dan dapat bersaing ditingkat Internasional. PT. A dalam susunan kepengurusannya terdiri dari dua orang komisaris, 1 orang direktur utama, 2 orang direktur, 3 manager dan lebih dari 50 orang staf serta telah memiliki sertifikat badan usaha (SBU) berkualitas besar dari INKINDO yang diregistrasi oleh lembaga pengembangan jasa konstruksi tingkat nasional (LPJKN). 
Aktivitas fungsi SDM belum efektif khususnya dalam hal komunikasi antara fungsi SDM kepada karyawan maupun direksi. Proses penyampaian informasi jarang dilakukan sehingga karyawan sangat sedikit mengetahui informasi terkait kebijakan perusahaan maupun keputusan - keputusan yang dikeluarkan direksi bahkan peraturan perusahaan juga tidak dipahami dengan baik oleh karyawan. Penyimpanan dokumen perusahaan yang tidak tertata dengan rapi sering menyulitkan dalam pencarian dokumen. Selain itu, ditemukan juga karyawan dengan bobot kerja yang tidak seimbang sehingga tidak menunjukkan produktivitas dalam bekerja.

Mengingat pentingnya audit sumber daya manusia dalam suatu organisasi khususnya di PT. "A", dan untuk mewujudkan perusahaan yang sehat dalam persaingan global serta untuk mengetahui masalah yang timbul dan menjadi gejolak para karyawan, maka rumusan permasalahan sebagai berikut: "Bagaimana hasil audit SDM dalam meningkatkan kualitas SDM PT. A"?

Tujuan dari audit SDM dimaksud, untuk memotret kondisi manajemen SDM secara keseluruhan dengan cara memperoleh informasi yang aktual dan signifikan sebagai dasar dalam pengambilan keputusan, pengendalian manajemen dan perbaikan untuk mencapai tujuan organisasi secara keseluruhan. Disamping itu dapat diketahuinya tipe kepribadian masing-masing karyawan yang terseleksi dengan memakai MBTI, khususnya untuk lebih memahami kepribadian karyawan.

\section{METODE PENELITIAN}

Untuk memperoleh informasi yang dibutuhkan terkait audit SDM dapat dilakukan dengan berbagai cara, dalam hal ini digunakan metode observasi, wawancara, study dokumen dan kuisioner.

Kuesione berdasar dari Audit SDM (Susilo, 2002) berupa SA 8000 dan daftar isian MBTI, sedangkan wawancara, studi dokumen dan observasi merupakan sarana pendamping untuk melengkapi hasil yang telah diperoleh.

\section{Instrumen Audit SDM}

Instrumen audit SDM sesuai dengan SA (Social Accountability) 8000, karenaSA 8000 dapat diimpelementasikan pada semua jenis perusahaan dan mengandung nilai - nilai universal. Menurut Susilo ( 2002) dengan mentaati semua ketentuan standar SA 8000 berarti perusahaan dapat terhindar dari konsekuensi hukum yang berlaku secara nasional maupun internasional. Dengan mengadopsi standar SA 8000 memungkinkan perusahaan mengembangkan dan menjalankan 
sistem manajemen sumberdaya manusia secara lebih lengkap karena mencakup aspek tanggung jawab sosial.

Aspek yang ada dalam SA 8000 antara lain pekerja anak, kerja paksa, keselamatan dan kesehatan, kebebasan berserikat dan hak mengadakan kesepakaan kerja bersama, diskriminasi, praktek pendisiplinan, jam kerja, remunerasi, sistem managemen SDM, daftar periksa fungis rekruitment, daftar periksa fungsi pelatihan, daftar periksa program penilaian karya dan daftar periksa sistem pengupahan

\section{Instrumen Tes MBTI}

Pemakaian alat MBTI (Myers Biggs Type Indicator) berdasarkan pada kesederhananan alat test ini serta bisa mengungkap kepribadian seseorang khususnya dalam pengambilan keputusan. Dalam Tes MBTI ini, ada 4 dimensi kecenderungan sifat dasar manusia dan saling dipertentangkan (http://www.sipedia.com/2014/04/pengertian-apa-itu-tes-kepribadian-mbti.htmIngertian Apa itu Tes Kepribadian MBTI) yaitu

1. Dimensi pemusatan perhatian: Introvert (I) vs. Ekstrovert (E)

2. Dimensi memahami informasi dari luar: Sensing (S) vs. Intuition (N)

3. Dimensi menarik kesimpulan \& keputusan: Thinking $(T)$ vs. Feeling $(F)$

4. Dimensi pola hidup: Judging (J) vs. Perceiving $(P)$

Masing-masing dimensi mempunyai 15 butir pernyatan sehingga total soal pernyataan ada 60 butir, dan dengan pilihan jawaban yang sudah ditetapkan (dengan tanda silang).

Berdasarkan dimensi dasar tersebut dihasilkan 16 tipe kepribadian manusia yang merupakan kombinasi dari 4 dimensi dasar tersebut. Kombinasi kepribadian MBTI ini adalah:

1. ESTJ : Extrovert, Sensing, Thinking, Judging

2. ENTJ : Extrovert, Intuition, Thinking, Judging

3. ESFJ : Extrovert, Sensing, Feeling, Judging

4. ENFJ : Extrovert, Intuition, Feeling, Judging

5. ESTP : Extrovert, Sensing, Thinking, Perceiving

6. ENTP : Extrovert, Intuition, Thinking, Perceiving

7. ESFP : Extrovert, Sensing, Feeling, Perceiving

8. ENFP : Extrovert, Intuition, Feeling, Perceiving

9. INFP : Introvert, Intuition, Feeling, Perceiving

10. ISFP : Introvert, Sensing, Feeling, Perceiving

11. INTP : Introvert, Intuition, Thinking, Perceiving 
12. ISTP : Introvert, Sensing, Thinking, Perceiving

13. INFJ : Introvert, Intuition, Feeling, Judging

14. ISFJ : Introvert, Sensing, Feeling, Judging

15. INTJ : Introvert, Intuition, Thinking, Judging

16. ISTJ : Introvert, Sensing, Thinking, Judging

\section{HASIL PENELITIAN}

Berdasarkan table SA 8000 (Susilo, 2000) diperoleh hasil sebagai berikut:

a. Pekerja anak.

Tidak ditemukan pekerja yang termasuk dalam kategori anak dalam perusahaan dan hal tersebut juga tercantum dalam Peraturan Perusahaan.

b. Kerja paksa.

Perusahaan tidak mempraktekkan kerja paksa bahkan terkesan memberikan kelonggaran kepada pegawai dalam bekerja dimana masih ditemukan pegawai datang tidak sesuai dengan jam yang sudah ditentukan perusahaan (masuk pukul $09.00-17.00 \mathrm{WIB}$ ).

c. Keselamatan dan kesehatan

1) Seluruh pegawai sejak bulan Oktober 2015 diberikan BPJS kesehatan dan ketenaga kerjaan.

2) Khusus untuk direktur dan dirut diberikan asuransi lainnya.

3) Untuk tingkat manager hanya manager keuangan dan pemasaran sementara manager lain tidak diberikan asuransi lainnya.

4) Tidak ada program ataupun upaya untuk mengidentifikasi kemungkinan bahaya yang timbul dalam lingkungan kerja baik saat berada didalam ruangan maupun diluar ruangan.

5) Perusahaan juga tidak memberikan pelatihan/informasi yang cukup kepada karyawan baik lama maupun baru terkait upaya penyelamatan ketika terjadi kecelakaan dalam lingkungan kerja.

6) Tidak ada jalur evakuasi

7) Tidak ada inventarisasi terkait asset perusahaan

d. Kebebasan berserikat dan hak mengadakan kesepakatan kerja bersama:

1) Perusahaan memberikan kebebasan kepada karyawan terkait hak untuk berserikat

2) Kesepakatan kerja bersama yang berlaku di perusahaan dibuat perusahaan tanpa melibatkan karyawan

e. Diskriminasi 
1) Perusahaan tidak memberikan diskriminasi kepada etnis, agama atau kelompok tertentu.

2) Tidak ada kejelasan tentang leveling karyawan

f. Praktek pendisiplinan

1) Dalam perusahaan tidak diberlakukan sanksi terkait kedisiplinan.

2) Terkait absensi juga kurang mendapatkan perhatian dari pihak perusahaan

3) Kebijakan yang berlaku saat ini masih mengacu pada kebijakan yang dibuat tahun 2006.

g. Jam kerja.

1) Meskipun secara tertulis ada peraturan yang mengatur tentang jam kerja namun masih ditemukan pegawai yang datang semaunya dan perusahaan juga tidak tegas dalam memberikan sangsi terkait masalah tersebut.

2) Meskipun syarat tentang lembur sudah sesuai dengan UU Ketenagakerjaan dan Peraturan perusahaan namun lembur tidak dibayarkan setiap bulannya oleh perusahaan.

h. Remunerasi, Sistem pengupahan tidak terdokumentasi dengan baik dan belum disesuaikan dengan Undang - Undang yang berlaku karena masih merujuk pada Peraturan Perusahaan tahun 2006 dan masih ditemukan pegawai dengan upah dibawah standar yang ditetapkan pemerintah.

i. Sistem managemen SDM

1) Perusahaan tidak memiliki dokumentasi terkait seluruh peraturan baik nasional / internasional menyangkut ketenagakerjaan.

2) Undang - Undang yang dipakai dalam Peraturan Perusahaan tahun 2006 mengacu pada Undang - Undang nomor 12 tahun 1964

3) Prinsip perbaikan terkait peningkatan gaji dilakukan belum berdasarkan tingkat produktifitas tiap karyawan dan hanya berdasarkan pertimbangan direktur secara personal

4) Kebijakan ketenagakerjaan yang berlaku (SOP lembur, rekruitmen dan seleksi) tidak dikomunikasikan secara intens kepada seluruh karyawan.

5) Perusahaan tidak melakukan tinjauan berkala kepada setiap karyawan.

6) Pembagian tugas dan tanggung jawab antara direktur, manager dan staf tidak berlaku secara jelas.

7) Tidak ada pelatihan / orientasi yang diberikan perusahaan kepada karyawan baru.

8) Perusahaan tidak melakukan pemantauan kinerja pegawai terkait masalah ketenagakerjaan yang terjadi dalam perusahaan 
9) Keluhan yang terjadi dalam perusahaan tidak disampaikan secara langsung dan belum mendapatkan perhatian yang serius.

j. Daftar periksa fungsi Recruitment.

1) Recruitment yang dilakukan belum berdasarkan man power planning.

2) Tidak ada catatan terkait proses rekruitmen

3) Tidak ada hasil evaluasi yang dilakukan saat masa orientasi karyawan baru.

4) Karyawan baru hanya mendapatkan surat kontrak yang berisi masa percobaan

5) Atribut karyawan termasuk nomor absensi karyawan tidak ada.

6) Karyawan baru tidak diberikan uraian pekerjaan secara jelas termasuk sistem pelaporan

k. Daftar periksa fungsi pelatihan

1) Pelatihan yang diberikan kepada karyawan bersifat insidentil dan bukan berdasarkan rencana kerja yang telah dibuat sebelumnya.

2) Perusahaan belum memiliki mekanisme analisis terkait kebutuhan kompetensi yang sistematis bagi karyawannya.

3) Tidak ada peta kompetensi di perusahaan dan pimpinan tidak terlibat langsung dalam analisis kebutuhan kompetensi.

4) Tidak terlihat alur tanggung jawab langsung pimpinan kepada bawahan.

5) Tidak adanya pengkaderan pemimpin dalam perusahaan untuk pengembangan usaha.

6) Perusahaan tidak memiliki modul terkait kegiatan yang dilakukannya saat ini

7) Catatan atau informasi yang didapat dari pelatihan tidak terdokumentasi dan tidak ada tranfers of learning kepada pegawai lain

I. Daftar periksa program penilaian karya

1) Penilaian terhadap karya dalam perusahaan dilaksanakan secara subjektif oleh pimpinan.

2) Tidak ada mekanisme dan prosedur terkait penilaian karya

m. Daftar periksa sistem pengupahan

1) Sistem pengupahan karyawan tidak memiliki sistem baku yang sesuai dengan peraturan.

2) Perusahaan tidak melalukan pengukuran kepuasan karyawan terkait sistem pengupahan yang diberlakukan

3) Pembayaran upah tidak dilengkapi dengan rincian penerimaan atau pemotongan.

4) Struk gaji tidak diberikan kepada karyawan.

5) Upah karyawan ditinjau berkala namun tidak setiap tahun. 
6) Sistem pengupahan tidak dikomunikasikan kepada pegawai

7) Masih ditemukan karyawan dengan upah dibawah UMR

Berdasarkan Tess MBTi didapatkan bahwa karyawan PT "A" menpunyai kecenderungan pada ESTJ (13 karyawan) dan ENTJ (8 karyawan dan lainnya tersebar di bawah 5 karyawan di semua tipe kepribadian. Makna dari hasil tersebut adalah mayoritas berkecenderungan bersosialisasi dan kebersamaan serta menginginkan adanya ketrraturan kerja. Selain itu terlihat tidak mentolerir ketidak mampuan teman sekerja.

\section{KESIMPULAN DAN SARAN}

Dari hasil audit yang dilakukan dapat disimpulkan bahwa:

1. Dalam PT."A", tidak ditemukan adanya pekerja anak dan kerja paksa, bahkan terkesan memberikan kelonggaran kepada pegawai dalam bekerja dimana masih ditemukan pegawai datang tidak sesuai dengan jam yang sudah ditentukan perusahaan.

2. Untuk seluruh pegawai mulai dari direksi hingga security sudah didaftarkan menjadi peserta BPJS kesehatan dan ketenagakerjaan bahkan untuk direksi juga ditambah dengan asuransi lain. Namun perusahaan belum mengidentifikasi kemungkinan bahaya yang timbul dalam lingkungan kerja baik saat berada didalam ruangan maupun diluar ruangan dan belum memberikan informasi yang cukup terkait hal tersebut kepada karyawan.

3. Perusahaan memberikan kebebasan kepada karyawan terkait hak untuk berserikat namun tidak melibatkan karyawan dalam membuat kesepakatan kerja bersama

4. Perusahaan tidak memberikan diskriminasi kepada etnis, agama atau kelompok tertentu

5. Tidak ada sanksi yang diberikan kepada karyawan terkait pelanggaran yang dilakukannya.

6. Tidak ada sistem dokumentasi dan inventarisasi baik terkait Undang - Undang atau peraturan terkait ketenagakerjaan, asset perusahaan maupun karyawan.

7. Kebijakan - kebijakan yang dibuat perusahaan tidak tersosialisasi dengan baik. Tidak ada tinjauan berkala, kejalasan tentang pembagian tugas dan tanggung jawab,

8. Terkait rekruitmen dan pelatihan hanya dilakukan ketika dibutuhkan dan tidak ada catatan terkait, proses hingga evaluasi. 
9. Pengupahan tidak tersistem dengan baik dan tidak dilakukan pengukuran terhadap kepuasan kerja karyawan serta tidak dikomunikasikan kepada karyawan.

10. Berdasarkan hasil tes MBTI diperoleh hasil bahwa kebersamaan merupakan tujuan utama dalam bekerja, sehingga semua terlibat dalam bekerja dan sangat tidak mentolerir akan ketidakmampuan teman sekerja.

\section{SARAN}

Berdasarkan hasil audit SDM serta kesimpulan hasil audit, maka:

a. Meningkatkan komunikasi diseluruh jajaran mulai dari direksi, manager hingga staf.

b. Memberikan penilaian dan tinjuan berkala yang sesuai dengan kinerja pegawai kepada perusahaan sehingga dapat meningkatkan motivasi dalam bekerja.

c. Merevisi peraturan perusahaan sesuai dengan Undang - Undang Nomor 13 tahun 2003 tentang ketenagakerjaan dan peraturan pemerintah yang terkait.

d. Membuat program kerja yang lebih baik dengan target yang disesuaikan dengan kemampuan perusahaan termasuk training atau pelatihan yang diberikan kepada pegawai.

e. Lebih tegas dalam mendisiplinkan karyawan sesuai dengan peraturan perusahaan yang telah dibuat.

f. Membuat job description yang lebih rinci,

g. Dengan memperhatikan hasil tes MBTI, maka lebih melihat kemampuan karyawan dalam penunjukkan tugas. 


\section{DAFTAR PUSTAKA}

http://www.si-pedia.com/2014/04/pengertian-apa-itu-tes-kepribadian-bti.htmlngertian Apa itu. Tes Kepribadian MBTI.

Kristi. E. Poerwandari. 1998. Pendekatan Kualitatif Untuk Penelitian Perilaku Manusia. Depok: LPSP3 Fakultas Psikologi Universitas Indonesia.

Susilo, W, 2002, Audit SDM: Panduan Komprehensif Auditor dan Praktisi Managemen Sumber Daya Manusia serta Pimpinan Perusahaan, PT Vorqistatama Binamega, Jakarta.

Undang - Undang Nomor 13 Tahun 2003 tentang Ketenagakerjaan. 